\title{
Excitatory amino acid binding sites in the hippocampal region of Alzheimer's disease and other dementias
}

\author{
J B Penney, W F Maragos, J T Greenamyre, D L Debowey, Z Hollingsworth, A B Young
}

\begin{abstract}
Quantitative receptor autoradiography was used to measure muscarinic cholinergic, benzodiazepine, kainate, phencyclidine (PCP), N-methyl-D-aspartate (NMDA) (measured in Tris acetate), quisqualate-sensitive, non-quisqualatesensitive and total glutamate (measured in Tris chloride buffer) binding sites in adjacent sections of the hippocampal region of 10 Alzheimer's disease, nine control, and six demented, non-Alzheimer's disease postmortem human brains. The measurements were compared to the number of neurofibrillary tangles as revealed by Congo red staining of adjacent sections. All assays and measurements were done by observers blinded to the clinical diagnoses. Binding was decreased significantly for all ligands except quisqualate in stratum pyramidale of CAl of the Alzheimer's disease brains. The binding loss was significantly greater for the non-quisqualate and NMDA sites than for the muscarinic, benzodiazepine and kainate sites with the total glutamate and PCP site losses being intermediate. Only the loss of benzodiazepine binding was significantly correlated with the number of neurofibrillary tangles. Lesser binding losses were seen in adjacent areas. This difference in the degree of binding decrease is consistent with the hypothesis that NMDA receptors are located on more distal dendrites of hippocampal neurons. There they may be relatively more vulnerable than the other receptors to the pathological process.
\end{abstract}

Department of Neurology and Neuroscience Program, University of Michigan, Ann Arbor, United States J B Penney W F Maragos J T Greenamyre D L Debowey $Z$ Hollingsworth A B Young

Correspondence to: Dr John B Penney Jr, Neuroscience Laboratory Building, University of Building, University of Michigan, 1103 East Huron 48104, United States.

Received 24 February 1989 and in revised form 18 August 1989. Accepted 18 September 1989 granule cells to the CA4 and CA3 regions of Ammon's horn, the Schaeffer collateral pathway from $\mathrm{CA} 3$ to $\mathrm{CA} 1$, and the $\mathrm{CA} 1$ and subicular projection pathways. ${ }^{2}$ Glutamate is known to interact with at least four different excitatory amino acid neurotransmitter receptors: the N-methyl-D-aspartate (NMDA) receptor, the quisqualic acid receptor, the kainate receptor and the metabotropic receptor. ${ }^{3-6}$ The first three of these appear to regulate ion channels. All three are present in hippocampal formation. ${ }^{34}$ The NMDA and quisqualate receptors are important in memory formation as blockade of these receptors alters long term potentiation (LTP), a presumed physiological analogue of learning in animals. ${ }^{7-10}$

There have been a number of studies of excitatory amino acid and other neurotransmitter receptors in the hippocampal formation of $\mathrm{AD}$ brains. These studies have employed a variety of techniques and have reported differing results. Serotonin receptors and $G_{A B A}$ receptors are significantly decreased in hippocampal formation. ${ }^{112}$ Some studies report decreases in muscarinic cholinergic receptors. ${ }^{1314}$ Others report little change in muscarinic or benzodiazepine receptors in the absence of significant cell loss. ${ }^{1516}$ Greenamyre et $a l^{16}$ found marked decreases in glutamate receptors measured in the presence of chloride ion. Others ${ }^{17}$ found lesser changes when glutamate receptors were measured in the presence of acetate ion rather than chloride. Changes in postsynaptic glutamate receptors have been found in homogenate studies. ${ }^{18}$ There have also been conflicting results in measurements of the PCP receptor which is linked to the NMDA receptor. Monaghan et $a l^{19}$ found no significant changes in the absence of cell loss. In a blinded study comparing AD brains to normal controls and to demented patients without $\mathrm{AD}$, Maragos et $a^{20}$ found a significant reduction in the number of PCP receptors. In a homogenate study of $\left[{ }^{3} \mathrm{H}\right] \mathrm{MK}$ 801 binding to the PCP receptor, no changes were observed. ${ }^{21}$ It is not clear whether the differences in the results from the various studies of excitatory amino acid receptors in $\mathrm{AD}$ are due to differences in the degree of pathology in the brains, to differences in the methods used to measure the receptors, or to other differences.

No studies in Alzheimer's hippocampus have directly measured one neurotransmitter receptor using different methods or compared the changes to those of other receptors, to local pathology, or to similar measurements in other dementing illnesses. Therefore, we measured 
Table 1 Characteristics of the 25 brains

\begin{tabular}{|c|c|c|c|c|}
\hline & Age & $\begin{array}{l}\text { Post } \\
\text { mortem } \\
\text { delay } \\
\text { (hours) }\end{array}$ & $\begin{array}{l}\text { Months } \\
\text { at }-70^{\circ} \mathrm{C}\end{array}$ & Chronic medications \\
\hline \multicolumn{5}{|l|}{ Controls: } \\
\hline C1 & 79 & 19 & 6 & Carbidopa/levodopa \\
\hline $\mathrm{C} 2$ & 67 & 20 & 23 & Digoxin, propanolol \\
\hline $\begin{array}{l}\mathrm{C} 3 \\
\mathrm{C} 4\end{array}$ & $\begin{array}{l}74 \\
22\end{array}$ & $\begin{array}{r}25 \\
9\end{array}$ & $\begin{array}{l}47 \\
47\end{array}$ & Metoprolol, nifedipine, nitrate \\
\hline $\mathrm{C} 5$ & 77 & 5 & 2 & Amitriptyline, haloperidol \\
\hline C6 & 64 & 17 & 48 & Nifedipine \\
\hline $\mathrm{C} 7$ & 69 & 6 & 5 & $\begin{array}{l}\text { Carbidopa/levodopa, bromocriptine, } \\
\text { amitriptyline, aminophylline }\end{array}$ \\
\hline $\mathrm{C} 8$ & 73 & 16 & 2 & Lorazepam, verapamil, digoxin, prednisone \\
\hline $\begin{array}{l}\text { C9 } \\
\text { Mean }\end{array}$ & 55 & 21 & 48 & \\
\hline $\begin{array}{l}\text { Mean } \\
\text { SEM }\end{array}$ & $\begin{array}{r}64 \cdot 4 \\
5 \cdot 8\end{array}$ & $\begin{array}{r}15 \cdot 3 \\
2 \cdot 4\end{array}$ & $\begin{array}{r}25 \cdot 3 \\
7 \cdot 3\end{array}$ & \\
\hline \multicolumn{5}{|c|}{ Alzheimer's disease: } \\
\hline Al & 73 & 40 & 31 & Chlordiazepoxide, doxepine \\
\hline A2 & 58 & 20 & 48 & \\
\hline $\begin{array}{l}\text { A3 } \\
\text { A4 }\end{array}$ & $\begin{array}{l}71 \\
84\end{array}$ & $\begin{array}{r}22 \\
8\end{array}$ & $\begin{array}{l}2 \\
6\end{array}$ & \\
\hline A5 & 83 & 6 & 9 & \\
\hline A6 & 69 & 14 & 31 & Hydroxyzine \\
\hline A7 & 65 & 14 & 38 & Haloperidol \\
\hline A8 & 62 & 15 & 45 & \\
\hline A9 & 77 & 22 & 14 & $\begin{array}{l}\text { Carbidopa/levodopa, phenytoin, phenobarbital, } \\
\text { dephenhydramine, amantadine }\end{array}$ \\
\hline A10 & 67 & 1 & 10 & Carbidopa/levodopa \\
\hline Mean & $70 \cdot 9$ & 16 & 23.4 & \\
\hline SEM & $2 \cdot 7$ & $3 \cdot 4$ & $5 \cdot 4$ & \\
\hline \multicolumn{5}{|c|}{ Demented non-Alzheimer's disease: } \\
\hline D1 & 68 & 7 & 24 & \\
\hline D2 & 73 & 12 & 20 & \\
\hline D3 & 69 & 9 & 10 & Haloperidol \\
\hline D4 & 68 & 12 & 55 & \\
\hline D5 & 63 & 15 & 25 & Phenytoin \\
\hline D6 & 69 & 17 & 5 & Insulin, prednisone, aminophylline \\
\hline Mean & $68 \cdot 3$ & 12 & $23 \cdot 3$ & \\
\hline SEM & $1 \cdot 3$ & 1.5 & $7 \cdot 1$ & \\
\hline
\end{tabular}

markers for muscarinic cholinergic receptors, benzodiazepine receptors, the NMDA subtype of glutamate receptors (measured in acetate buffer), total quisqualate-sensitive and nonquisqualate sensitive glutamate receptors (measured in chloride buffer), PCP receptors and kainate receptors in serial sections from nine control, $10 \mathrm{AD}$ and six demented non-AD brains. We compared these measurements to those of neurofibrillary tangles as revealed by Congo red staining of serial sections of the same brains. This report presents our results.

\section{Methods}

Human brains were obtained at necropsy and samples of brain material were stored as 1 inch slabs at $-70^{\circ} \mathrm{C}$. For this study, blocks of medial temporal lobe containing rostral hippocampus were removed from the slab by one of us (JBP) and presented as coded samples to the other investigators who performed all binding assays and data analysis. Only after the data analysis was complete, was the code broken and were statistical comparisons made. Nine nondemented, $10 \mathrm{AD}$ and six non-AD brains were used (table 1). Two of the non-demented and two of the AD cases had coexistent Parkinson's disease. The other non-demented çases died of nonneurological disease. The Alzheimer's cases varied from early to late disease. The diagnosis of Alzheimer's disease was made if the criteria of Khachaturian et al ${ }^{22}$ were met for some region of cortex. The demented, non-AD brains included one case of Pick's disease, one of progressive aphasia and four of diffuse cortical atrophy and striatal and cortical gliosis without plaques or tangles.
The non-demented patients died of cardiac disease. Several had other diseases including the two with Parkinson's disease. Three had been chronically treated with calcium channel blockers, two each with carbidopa/levodopa, beta blockers, nitrates, and amitriptyline, and one each with haloperidol, aminophylline, bromocriptine, steroids and benzodiazepines. Terminally two each were treated with antibiotics, atropine, and dopamine while one each was treated with pancuronium, isoproterenol, heparin, furosemide and opiates. The demented patients had received fewer medications. Two of the Alzheimer's disease patients had received carbidopa/levodopa and one each had received haloperidol, benzodiazepines, doxepin, hydroxyzine, amantadine, phenobarbital, phenytoin and diphenhydramine. Terminally one each received epinephrine, isoproterenol and atropine. One of the non-Alzheimer's demented cases had received haloperidol, one aminophylline and one steroids. Terminally one had been given antibiotics and one furosemide.

From each block, serial, 20 micron thick sections were obtained. Two were stained for neurofibrillary tangles with Congo red, two for acetylcholinesterase, and the rest were processed for receptor autoradiography as described in table 2 . Table 2 details the buffers, washes and blanks used in the assays. All assays were carried out on triplicate sections. Because of the number of sections to be cut and the number of assays to be performed, not all the brains could be assayed on the same day, nor could all the assays be performed at the same time. Because we have found that the number of measurable glutamate, but not of other, receptors declines over days when sections are stored at $-20^{\circ} \mathrm{C}$, glutamate receptor assays were carried out on the day of sectioning. Therefore, the brains were divided into two groups with roughly equal numbers of each clinical diagnosis in each group. The sections from the first group of brains were obtained for the NMDA, muscarinic, benzodiazepine, kainate, Congo red and cholinesterase assays. The NMDA assay was carried out on the day of sectioning. The next day the second group was sectioned for the same assays and the NMDA assay carried out. The other assays were done on subsequent days. After these assays were performed, additional sections were obtained from the first group of blocks for the assays of total glutamate and non-quisqualate-sensitive glutamate binding in chloride buffer. These assays were then performed on the day of sectioning. The same procedure was then used to run the same two glutamate binding assays on the other group of brains.

Autoradiograms were generated by exposing the sections to Ultrofilm ${ }^{3} \mathrm{H}$ (LKB). Quantitative densitometry was performed blindly by observers who compared readings from the regions of interest to those from the standards containing known amounts of radioactivity. ${ }^{23}$ The number of quisqualate displaceable binding sites was calculated by subtracting binding remaining in the presence of $2.5 \mu \mathrm{M}$ quisqualate (NMC) from total glutamate bind- 
Table 2 Details of the Ligand Binding Assays

\begin{tabular}{|c|c|c|c|c|c|}
\hline Abbreviation & Receptor & Ligand & Concentration & Blank & Buffer \\
\hline $\begin{array}{l}\text { QNB } \\
\text { FLU } \\
\text { TCP }\end{array}$ & $\begin{array}{l}\text { Muscarinic cholinergic } \\
\text { Benzodiazepine } \\
\text { PCP }\end{array}$ & $\begin{array}{l}{\left[{ }^{3} \mathrm{H}\right] \text {-quinuclidinyl benzilate }} \\
{\left[{ }^{3} \mathrm{H}\right] \text {-flunitrazepam }} \\
\left.\left[{ }^{3} \mathrm{H}\right]-\mathrm{N} \text {-(1-[2-thienyl]cyclohexyl }\right) \\
\text { 3,4-piperidine }\end{array}$ & $\begin{array}{r}1 \mathrm{nM} \\
25 \mathrm{nM} \\
20 \mathrm{nM}\end{array}$ & $\stackrel{\star}{\star} 10 \mu \mathrm{M}$ TCP & $\begin{array}{l}\text { Dulbecco's phosphate buffered saline, } \mathrm{pH} 7.4 \\
50 \mathrm{mM} \text { Tris citrate, pH } 7 \cdot 0 \\
50 \mathrm{mM} \text { Tris acetate with } 1 \mathrm{mM} \mathrm{Mg} \text { acetate, } \\
\text { pH } 7.4\end{array}$ \\
\hline NMA & N-methyl-D-aspartate & {$\left[{ }^{3} \mathrm{H}\right]$-glutamate } & $200 \mathrm{nM}$ & $1 \mathrm{mM}$ glutamate & $\begin{array}{l}50 \mathrm{mM} \text { Tris acetate, pH } 7.2 \text { plus } 2.5 \mu \mathrm{M} \\
\text { quisqualic acid }\end{array}$ \\
\hline $\begin{array}{l}\text { GLC } \\
\text { NMC }\end{array}$ & $\begin{array}{l}\text { Total glutamate } \\
\text { Non-quisqualate }\end{array}$ & $\begin{array}{l}{\left[{ }^{3} \mathrm{H}\right] \text {-glutamate }} \\
{\left[{ }^{3} \mathrm{H}\right] \text {-glutamate }}\end{array}$ & $\begin{array}{l}200 \mathrm{nM} \\
200 \mathrm{nM}\end{array}$ & $\begin{array}{l}1 \mathrm{mM} \text { glutamate } \\
1 \mathrm{mM} \text { glutamate }\end{array}$ & $\begin{array}{l}50 \mathrm{mM} \text { Tris } \mathrm{HCl} \text { plus } 2.5 \mathrm{mM} \mathrm{CaCl}_{2}, \mathrm{pH} 7.2 \\
50 \mathrm{mM} \text { Tris } \mathrm{HCl}, 2.5 \mathrm{mM} \mathrm{CaCl} \\
+2.5 \mu \mathrm{MH} \text { quisqualic acid }\end{array}$ \\
\hline KA & Kainic acid & {$\left[{ }^{3} \mathrm{H}\right]$-kainic acid } & $60 \mathrm{nM}$ & $100 \mu \mathrm{M} \mathrm{KA}$ & $50 \mathrm{mM}$ Tris acetate, $\mathrm{pH} \mathrm{7.2}$ \\
\hline
\end{tabular}

$\star$ Blanks were not used for the $\left[{ }^{3} \mathrm{H}\right]$-quinuclidinyl benzilate and $\left[{ }^{3} \mathrm{H}\right]$-flunitrazepam assays as blank values have always been undetectable in our previous studies.

Details of the Ligand Binding Assays

\begin{tabular}{|c|c|c|c|c|}
\hline Abbreviation & Prewash & Incubation & Rinse & Exposure time \\
\hline $\begin{array}{l}\text { QNB } \\
\text { FLU } \\
\text { TCP } \\
\text { NMA }\end{array}$ & $\begin{array}{l}2 \times 5 \min \left(a 0^{\circ} \mathrm{C}\right. \\
3 \times 5 \min @ 0^{\circ} \mathrm{C} \\
30 \min \left(a 0^{\circ} \mathrm{C}\right. \\
30 \min \left(0^{\circ} \mathrm{C}\right.\end{array}$ & $\begin{array}{l}3 \mathrm{hrs}\left(20^{\circ} \mathrm{C}\right. \\
30 \mathrm{~min}\left(4^{\circ} \mathrm{C}\right. \\
45 \min \cong 0^{\circ} \mathrm{C} \\
45 \min \left(0^{\circ} \mathrm{C}\right.\end{array}$ & $\begin{array}{l}2 \times 5 \text { min plus a } \mathrm{H}_{2} \mathrm{O} \text { dip } \\
2 \times 5 \mathrm{~min} \\
3 \times 1 \mathrm{~min} \\
4 \times 3 \mathrm{ml} \text { squirts of buffer, } 2 \times 2 \mathrm{ml} \text { squirts of } 2.5 \% \text { glutaraldehyde in }\end{array}$ & $\begin{array}{l}10 \text { days } \\
10 \text { days } \\
6 \text { weeks } \\
3 \text { weeks }\end{array}$ \\
\hline GLC & $30 \min \left(a 0^{\circ} \mathrm{C}\right.$ & $45 \min \left(a 0^{\circ} \mathrm{C}\right.$ & $\begin{array}{l}4 \times 3 \mathrm{ml} \text { squirts of buffer, } 2 \times 2 \mathrm{ml} \text { squirts of } 2.5 \% \text { glutaraldehyde in } \\
\text { acetone, total time }<10 \text { secs }\end{array}$ & 3 weeks \\
\hline NMC & $30 \min \left(a 0^{\circ} \mathrm{C}\right.$ & $45 \min \left(a 0^{\circ} \mathrm{C}\right.$ & $\begin{array}{l}4 \times 3 \mathrm{ml} \text { squirts of buffer, } 2 \times 2 \mathrm{ml} \text { squirts of } 2.5 \% \text { glutaraldehyde in } \\
\text { acetone, total time }<10 \text { secs }\end{array}$ & 3 weeks \\
\hline KA & $30 \min \left(a 2^{\circ} \mathrm{C}\right.$ & $45 \min \left(22^{\circ} \mathrm{C}\right.$ & $\begin{array}{l}4 \times 3 \mathrm{ml} \text { squirts of buffer, } 2 \times 2 \mathrm{ml} \text { squirts of } 2.5 \% \text { glutaraldehyde in } \\
\text { acetone, total time }<10 \text { secs }\end{array}$ & 10 weeks \\
\hline
\end{tabular}

ing (GLC) in each region of interest from each brain. The number of neurofibrillary tangles on the Congo red stained sections was counted in three fields from each of the five regions of interest of the hippocampal formation by one of us (ABY) who was also blind to the diagnoses of the patients.

In the statistical analyses the values from each region of interest from the different diagnostic groups were compared with one-way ANOVA and subsequent Newman-Keuls test to directly compare groups when the ANOVA indicated a significant result. For illustrative purposes the control and Alzheimer's groups were also compared using $t$ tests. Correlations between receptor levels and the number of neurofibrillary tangles in each region were performed using the Pearson product-moment coefficient. To determine if performing the

Table 3 Number of neurofibrillary tangles, per $20 \times$ field in hippocampal subregions of the 25 brains

\begin{tabular}{|c|c|c|c|c|c|}
\hline Brain & $\begin{array}{l}\text { Dentate } \\
\text { gyrus }\end{array}$ & $C A 3$ & $C A 1$ & Subiculum & Presubiculum \\
\hline \multicolumn{6}{|c|}{ Controls: } \\
\hline C1 & 0 & 0 & 1 found & 0 & 0 \\
\hline $\mathrm{C} 2$ & 0 & 0 & 0 & 0 & 0 \\
\hline C3 & 0 & 0 & 0 & 0 & 0 \\
\hline $\mathrm{C} 4$ & 0 & 0 & 0 & 0 & 0 \\
\hline $\mathrm{C} 5$ & 0 & - & 0 & 0 & 0 \\
\hline C6 & 0 & - & 0 & 0 & - \\
\hline C7 & 0 & 0 & 0 & 0 & 0 \\
\hline C8 & 0 & 0 & 0 & 0 & 0 \\
\hline C9 & 0 & 0 & 0 & 0 & 0 \\
\hline \multicolumn{6}{|c|}{ Alzheimer's disease: } \\
\hline A1 & $1-2$ & $<1$ & $4-6$ & $6-12$ & $3-6$ \\
\hline $\mathrm{A} 2$ & 0 & 0 & $2-5$ & $15-30$ & $<1$ \\
\hline A3 & 0 & 0 & $6-10$ & $1-2$ & 0 \\
\hline A4 & - & - & $8-10$ & $2-4$ & $<1$ \\
\hline A5 & 0 & $<1$ & $8-12$ & $30-60$ & $0-4$ \\
\hline A6 & 0 & - & $20-40$ & $60-80$ & $<1$ \\
\hline A7 & 0 & 0 & $15-30$ & $30-50$ & $0-3$ \\
\hline A8 & 0 & Rare & $0-2$ & $0-2$ & 0 \\
\hline A9 & $\mathbf{0}$ & 0 & $15-30$ & $6-8$ & 0 \\
\hline A10 & 0 & 0 & $0-2$ & $2-4$ & Rare \\
\hline \multicolumn{6}{|c|}{ Demented non-Alzheimer's disease: } \\
\hline D1 & 0 & 0 & 0 & 0 & 0 \\
\hline D2 & 0 & 0 & 0 & 0 & 0 \\
\hline D3 & 0 & - & 0 & 0 & 0 \\
\hline D4 & $\mathbf{0}$ & 0 & 0 & 0 & 0 \\
\hline D5 & 0 & 0 & $0-2$ & 0 & 0 \\
\hline D6 & 0 & $\mathbf{0}$ & 0 & 0 & 0 \\
\hline
\end{tabular}

assays on two different days affected the results, the different diagnostic groups were compared across the different days using a twoway ANOVA. Multiple regression analyses were used to determine which factors (disease state, age, post-mortem delay or freezer storage time) contributed to the differences in binding between the brains.

\section{Results}

There were no significant differences between the groups in their ages, postmortem delays or storage times in the freezer (table 1). There was no significant effect on the results of performing the assays on different days.

The number of neurofibrillary tangles found in a $20 \times$ field of the various subregions of the hippocampal formation in the brains is shown in table 3. The regions examined for tangles were the granule cell layer of dentate gyrus, the pyramidal layers of regions CA1 (SP1) and CA3 (CA3) of Ammon's horn, the subiculum (SUB) and the principal external layer of presubiculum (LPP). The Congo red staining revealed a wide range in the number of neurofibrillary tangles and senile plaques in the $\mathrm{AD}$ brains. Plaques and tangles were most common in subiculum and CA1.

Autoradiographic measurements of ligand binding were made in synaptic zones, including the molecular layers of dentate gyrus (DG) and CA1 (SM1), stratum pyramidale and (for kainate) stratum lucidum of CA3. Also, SP1, SUB, and LPP. Histograms showing the results of the measurements are shown in fig 1. Imageprocessing-computer generated pictures of muscarinic, benzodiazepine, PCP and NMDA binding to representative hippocampi are shown in fig 2 .

In the normal hippocampus, muscarinic binding was highest in SP1 with high binding in SUB and DG. Benzodiazepine binding was highest in DG with slightly lower amounts in SP1 and the perihippocampal regions; there was very little benzodiazepine binding in CA3. 

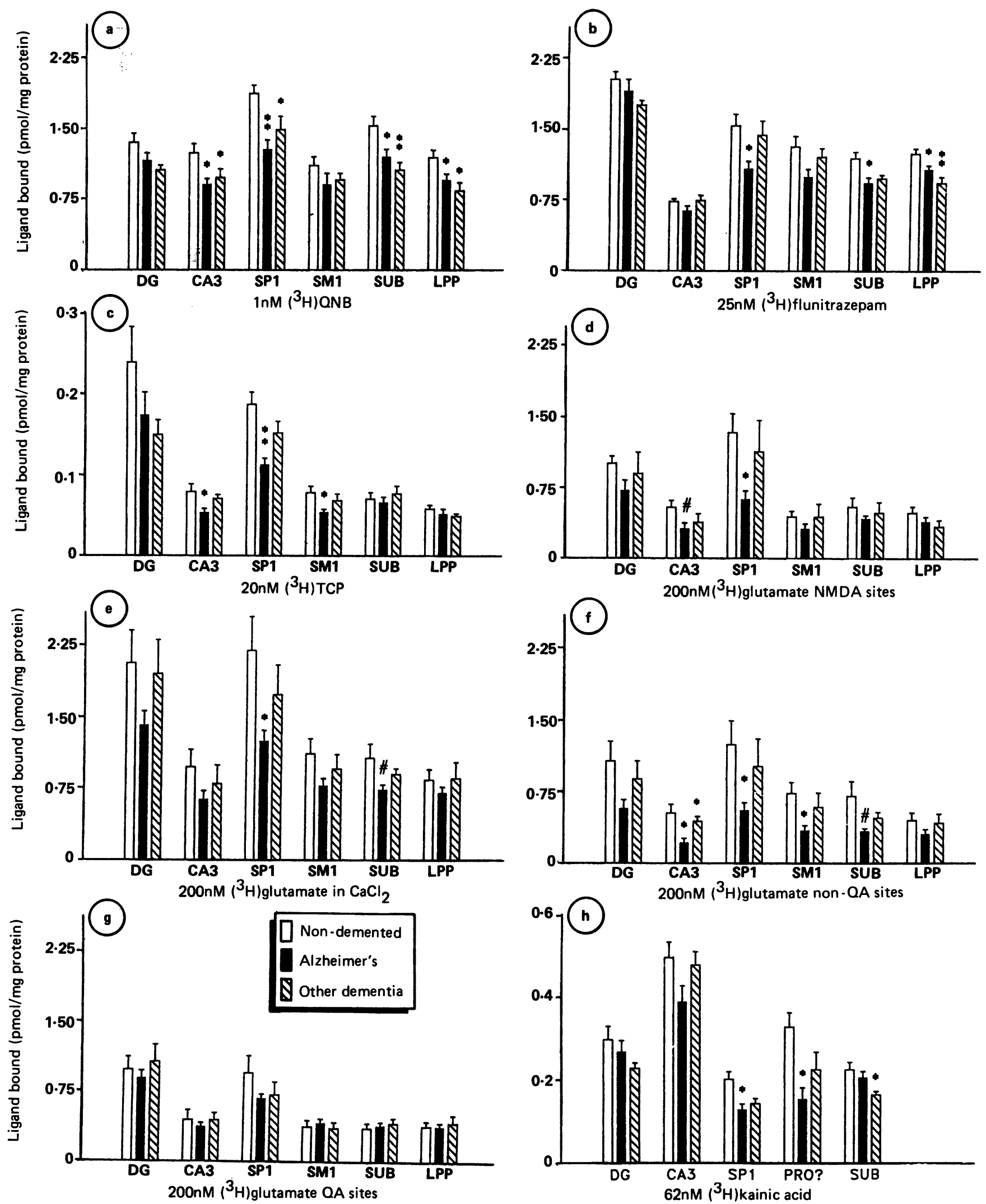

Fig 1 Histograms of binding to six subregions of hippocampus for each of the assays used. Error bars represent standard error of the mean, ${ }^{\star}: p<$ 0.05 by Newman-Keuls; ${ }^{\star}: 0<0.01$ by Newman-Keuls; \#: $p<0.05$ in comparing Alzheimer's to control brains by $t$ test when ANOVA is nonsignificant. Abbreviations of hippocampal subregions measured: DG: Stratum moleculare of dentate gyrus. CA3: Stratum pyramidale of CA3 (except stratum lucidum was measured in kainate assays). SP1: Stratum pyramidale of CA1. SM1: Stratum moleculare of CA1. SUB: Subiculum. LPP: Lamina principalis externa of presubiculum. PRO?: Prosubiculum? a: Muscarinic cholinergic receptors. $b$ : Benzodiazepine receptors. $c:$ PCP receptors. $d: N M D A$ receptors measured in acetate buffer. $e:$ Total glutamate binding in chloride and calcium. $f:$ Non-quisqualate displaceable glutamate binding in chloride and calcium (NMDA and "other" binding sites).g: Quisqualate displaceable glutamate binding. $h$ : Kainate receptors. 
Fig 2 Computer generated images of receptor binding to adjacent sections from four representative hippocampi under the different assay conditions. The top left hippocampus is from a control brain (C9). The top right from a patient with severe dementia, diffuse cortical and basal ganglia atrophy and gliosis without senile plaques or neurofibrillary tangles (D4). The bottom left is from a brain with mild Alzheimer's disease changes ( $A 8$ ). The bottom right is from a brain with severe Alzheimer's changes (A7). Abbreviations as in fig 1. A: Muscarinic cholinergic receptors. $B$ : Benzodiazepine receptors. $C: P C P$ receptors. D: NMDA receptors measured in acetate buffer.

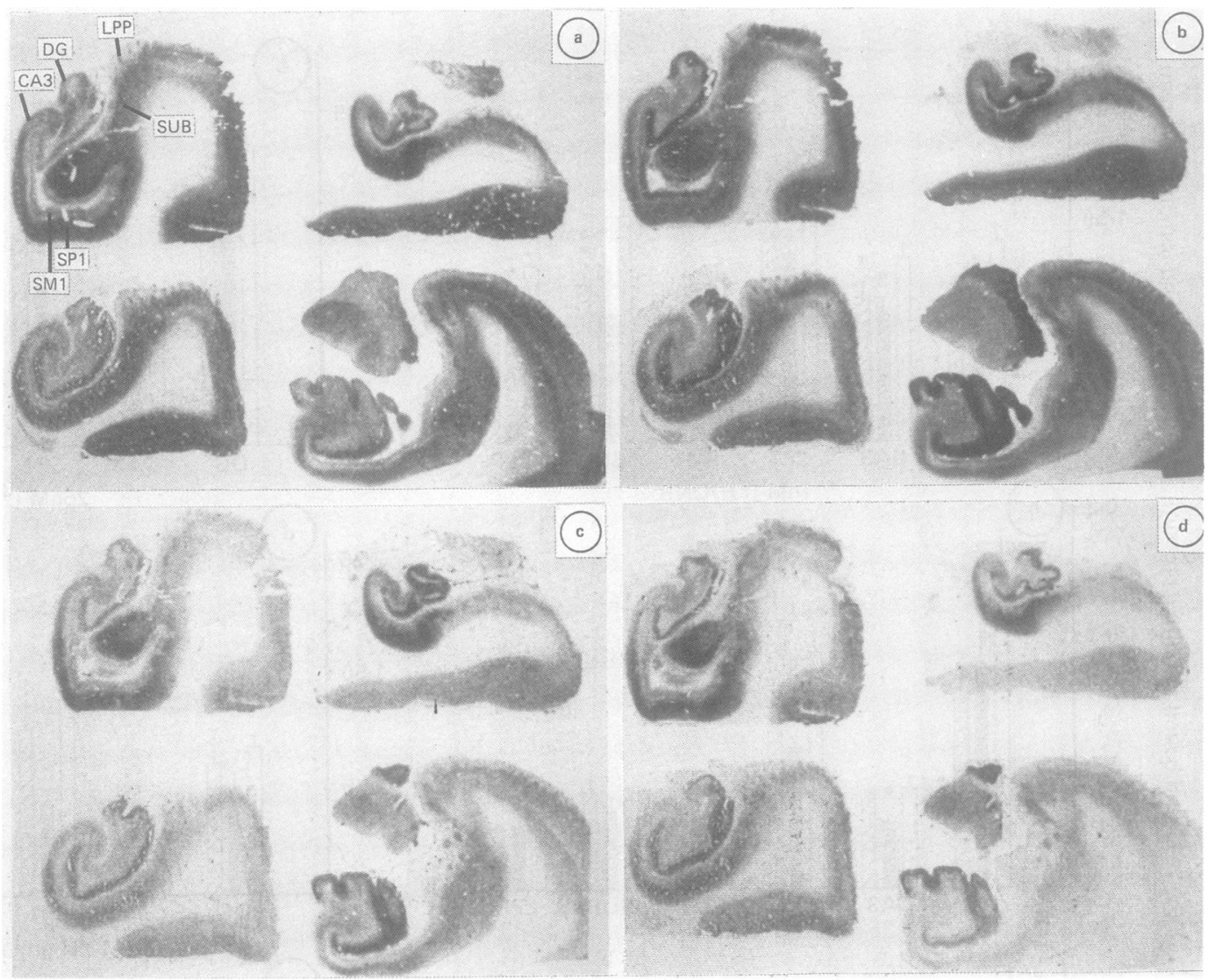

PCP and NMDA binding (measured in Trisacetate buffer) were highest in DG and SP1 with lower values in the other regions. In Trischloride buffer, total glutamate binding and binding in the presence of quisqualate tended to be enhanced in all regions compared to binding in Tris-acetate. The amount of binding displaced by quisqualate was high only in DG. Kainate binding was highest in stratum lucidum of CA3 and DG. There was a narrow band of high kainate binding in a region adjacent to SP1 that was probably prosubiculum.

In this group of Alzheimer's disease brains there were decreases in all receptors measured (figs 1 and 2). The degree of reduction was most marked in SP1 with lesser but consistent reductions in the subiculum. No significant reductions were found in DG. Only a few ligands were reduced in CA3, SM1 or LPP.

The only drugs the patients had been given that might have interacted with the receptors measured in this study were amytriptyline, benzodiazepines and phenobarbital. The benzodiazepines and phenobarbital had no apparent effect on flunitrazepam binding since binding in the treated cases did not differ from binding in the untreated ones. However, in the two nondemented cases that had been treated with amitriptyline, muscarinic cholinergic binding was significantly increased compared with that in the other cases $\left(F_{1,5,5,34}=18.09 ; p\right.$ $<0.001$ by 2 way ANOVA). If these two cases were excluded from analysis of muscarinic binding then muscarinic binding to DG was $1.25 \mathrm{pmol} / \mathrm{mg}$ protein (SEM 0.11 ), binding to CA3 was $1.063(0 \cdot 16)$, binding to SP1 was 1.79 (0.09), binding to SM1 was $1.07(0.11)$, binding to SUB was $1.39(0.07)$ and binding to LPP was $1 \cdot 15(0.09)$. With the two cases excluded the only significant decreases of muscarinic binding in the diseased brains were to SP1 of Alzheimer's brain ( $p<0.05$ by NewmanKeuls) and to SUB of the nonAlzheimer's brains ( $p<0.05$ by NewmanKeuls).

The only binding levels that correlated significantly with the number of neurofibrillary tangles within the Alzheimer's brains were benzodiazepine binding in SP1 $(r=0.804 ; p<$ $0.01)$ and muscarinic binding in LPP $(r=$ $0.630 ; p<0.05)$. Multiple linear regression

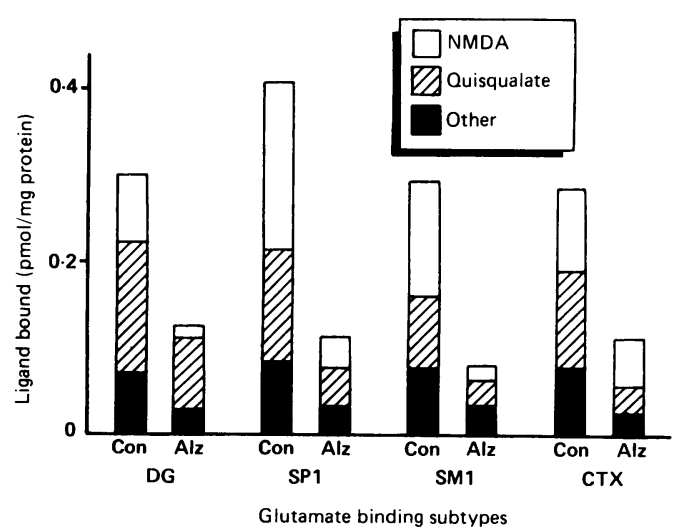

Fig 3 Reanalysis of the data of Greenamyre et al. NMDA receptors were defined as glutamate binding displaced by $100 \mu M N M D A$. Quisqualate receptors were defined as glutamate binding displaced by $2.5 \mu M$ quisqualate. "Other" binding is defined as -glutamate binding displaced by $1 \mathrm{mM}$ glutamate which is not displaced by $100 \mu M N M D A$ plus $2 \cdot 5 \mu M$ quisqualate. Abbreviations: CON: Control; AD: Alzheimer's disease. 
analysis was performed for DG and SP1 to determine which factors (disease state, age, post mortem delay or storage time) might contribute to the differences in ligand binding between the brains. Only disease state, not age, post mortem delay or storage time was found to significantly affect binding for all ligands.

In SP1, binding of all the ligands, except quisqualate-sensitive glutamate binding, to Alzheimer's disease brains was significantly below control values. The percentages of decline from mean control binding levels was compared among the ligands using one-way ANOVA. A significant difference between the ligands was found $\left(F_{6,63}=3.010, p=0.012\right)$. In pairwise comparisons using the Duncan multiple range test, the declines in NMDA and non-quisqualate-sensitive binding were significantly greater than the muscarinic, benzodiazepine, quisqualate and kainate declines ( $p$ $<0.05$ for each comparison). There were no other significant differences between pairs of ligands.

\section{Discussion}

The distribution of hippocampal binding was very similar for the different ligands with the exception of quisqualate and kainate. Binding was high in the synaptic zones of the dentate gyrus, CA1, subiculum and presubiculum. For most ligands it was highest in a broad band over stratum pyramidale of CA1. In humans this region contains the $\mathrm{CA} 1$ pyramidal cell bodies and many of their apical and basal dendrites, thus corresponding to the strata pyramidale, radiatum and oriens of rodents. ${ }^{24}$ Quisqualatesensitive glutamate binding was high only in the dentate molecular layer. For kainate, binding was highest to stratum lucidum of $\mathrm{CA} 3$ and the inner portion of the dentate molecular layer.

The regions of medial temporal lobe with the largest degree of cell loss, neurofibrillary tangles and senile plaques in Alzheimer's disease are the entorhinal cortex (layers 2 and 4), $\mathrm{CA} 1$ and subiculum. ${ }^{125}$ Unfortunately, entorhinal cortex was not present on the sections removed from many of the brains examined in this study so no attempt was made to analyse data from that region. Although no direct measure of cell loss was made, the counts of tangles (table 3 ) suggests that the pathological severity in these brains ranged from mild to severe. The areas in which there were binding losses were generally those in which there was also the most marked pathology. Areas with severe pathology, however, did not always display receptor loss. The subiculum, for instance, had severe histological pathology but relatively little loss of excitatory amino acid binding. There were no significant losses in dentate gyrus and only muscarinic and benzodiazepine binding were down slightly in LPP.

The magnitude of the muscarinic and benzodiazepine binding changes found in these brains was similar to that found by Greenamyre et al. ${ }^{16}$ However, in the current study the changes were significant. The decreases seen are unlikely to reflect simple cell damage as reflected in the number of neurofibrillary tangles. Only flunitrazepam binding loss in SP1 correlated with the number of neurofibrillary tangles. This correlation may reflect a localisation of benzodiazepine receptors on proximal dendrites of hippocampal neurons while the other receptors may be located on more distal dendrites where the pathological process begins. ${ }^{26-29}$ However, even for flunitrazepam, there was a significant decrease in the presubiculum, a region with little cellular pathology.

Quisqualate displaceable binding was high in dentate gyrus and low in the other regions measured. There were no significant changes in the Alzheimer's disease brains.

Kainate receptor binding was highest in CA3 and dentate gyrus. However, even though kainate binding in SP1 was low in all the brains, there was a significant decrease in binding to SP1 of the Alzheimer's disease brains. In addition in normal brains there was a more dense band of binding along the lateral border of CA1 that was much reduced or missing in the AD brains. It may be that this represents binding in the prosubiculum, a region of severe pathology in Alzheimer's disease [BT Hyman, personal communication]. Geddes et al ${ }^{30}$ described expansion in width of the band of $\left[{ }^{3} \mathrm{H}\right]$ kainate binding in dentate gyrus in $\mathrm{Alz}$ heimer's disease. We did not specifically study that issue in this study.

In other studies, we have found an extremely high correlation between the density of NMDA binding sites and PCP binding sites in adult rats. ${ }^{31}$ There was a good correlation between NMDA and PCP in the normal brains in this study $(r=0.616, p<0.001)$. Such a correlation is expected considering the biochemical data suggesting that the two sites exist on different parts of the same receptor ion channel complex.

Previously, we demonstrated large decreases in NMDA receptor binding in Alzheimer's hippocampus. ${ }^{16}$ In that study, we assayed $\left[{ }^{3} \mathrm{H}\right]$ glutamate binding in Tris-chloride buffer. We assessed quisqualate-sensitive and quisqualate-insensitive glutamate binding as measures of quisqualate and NMDA receptors respectively. However, quisqualate-insensitive glutamate binding is probably not a selective measure of NMDA receptors. Quisqualateinsensitive glutamate binding is much greater in chloride buffer than in acetate buffer and not all the binding in chloride buffer that remains in the presence of $2.5 \mu \mathrm{M}$ quisqualate is blocked by $500 \mu \mathrm{M}$ NMDA. We have reanalysed the data of Greenamyre et al (fig 3) using only measures of quisqualate-sensitive and NMDA-sensitive glutamate binding. This reanalysis confirms the presence of the large decreases in NMDA receptors reported in that study and suggests that the reported changes were not substantially influenced by methodology. The cases in that previous report, however, were all affected with severe pathology. It is likely, when comparing the results of this study with those of the previous report, that the degree of receptor loss reflects the degree of cellular pathology. 
The greater degree of loss of non-quisqualate and NMDA receptors than of muscarinic, benzodiazepine and kainate receptors may reflect a distal dendritic localisation of NMDA/ PCP receptors, since the distal dendrites and spines of pyramidal cells are thought to be affected first in $\mathrm{AD} .{ }^{26-29}$ Overall, those areas with greatest glutamate receptor losses were those in which there is significant pathology in AD. However, subiculum receptors were less affected than those in SP1 but pathologically these regions are similarly affected.

The regional specificity of pathology in AD has similarities with the density of NMDA receptors in the brain. ${ }^{17} 32$ However, there are several areas in which there are dense NMDA receptors and very little pathology. These include primary visual, auditory and sensory cortices (unpublished observations). These discrepancies suggest that excitotoxicity is unlikely to play a primary role in AD. Cells which have compromised metabolic function as a result of the disease process could become more vulnerable to excitotoxic damage as a secondary phenomemon. ${ }^{32} 33$

We thank Constance J D'Amato and Samuel Hicks for the pathological diagnoses, Suyin Liang for secretarial assistance and Kevin O'Mara for photographic assistance. This work was supported by USPHS Grants NS15655 and AG06155, the Arbogast Foundation, Roy $P$ Gettel and the Fraternal Order of Eagles.

1 Hyman BT, Van Hoesen GW, Damasio AR, Barnes CL Alzheimer's disease: cell-specific pathology isolates the hippocampal formation. Science 1984;225:1168-70.

2 Fonnum F. Glutamate: a neurotransmitter in mammalian brain. $J$ Neurochem 1984;42:1-11.

3 Greenamyre JT, Olsen JMM, Penney JB, Young AB. Autoradiographic characterization of N-methyl-D-aspartate-, quisqualate- and kainate-sensitive glutamate binding sites. J Pharmacol Exp Ther 1985;233:254-63.

4 Monaghan DT, Yao D, Cotman CW. L- $\left[{ }^{3} \mathrm{H}\right]$ glutamate Monaghan DT, Yao D, Cotman CW. L-['H]glutamate
binds to kainate-, NMDA- and AMPA-sensitive binding binds to kainate-, NMDA- and AMPA-sensitive binding
sites: an autoradiographic analysis. Brain Res 1985;340: sites: an

5 Nicoletti F, Meek JL, Iadarola MJ, Chuang DM, Roth BL, Costa E. Coupling of inositol phospholipid metabolism with excitatory amino acid recognition sites in rat hippocampus. J Neurochem 1985;46:40-6.

6 Sladeczak F, Pin JP, Recasens M, Bockaert J, Weiss S. Glutamate stimulates inositol phosphate formation in striatal neurones. Nature 1985;31 7:717-20.

7 Harris EW, Ganong AH, Cotman CW. Long-term potentiation in rat hippocampus involves activation of $\mathrm{N}$ methyl-D-aspartate receptors. Brain Res 1984:323.132-7.

8 Collingridge GL Ln term potentiation of the hippoca pus: Mechanisms of initiation and modulation by

9 Izumi Y, Miyakawa H, Ito K-I, Kato H. Quisqualate and nmethyl-D-aspartate (NMDA) receptors in induction of hippocampal long-term facilitation using conditioning solution. Neurosci Lett 1987;83:201-6.

10 Neuman $R$, Cherubini $E$, Ben-Ari $Y$. Is activation of $N$ methyl-D-aspartate receptor gated channels sufficient to induce long term potentiation? Neurosci Lett 1987;80: 283-8.

11 Cross AJ, Crow TJ, Ferrier IN, Johnson JA, Bloom SR, Corsellis JAN. Serotonin receptor changes in dementia of the Alzheimer type. J Neurochem 1984;43:1574-81.

12 Chu DCM, Penney JB Jr, Young AB. Quantitative autoradiography of hippocampal GABA and GABA receptor changes in Alzheimer's disease. Neurosci Lett 1987;82:246-52.

13 Shimohama S, Taniguchi T, Fujiwara $M$, Kameyama $M$ Changes in nicotinic and muscarinic cholinergic receptors in Alzheimer-type dementia. J Neurochem 1986;46:28893.

14 Waller SB, Ball MJ, Reynolds MA, London ED. Muscarinic binding and choline acetyltransferase in postmortem brains of demented patients. Can J Neurol Sci 1986;13: 528-32.

15 Palacios JM. Autoradiographic localization of muscarinic cholinergic receptors in the hippocampus of patients with senile dementia. Brain Res 1982;243:173-5.

16 Greenamyre JT, Penney JB, D'Amato CJ, Young AB Dementia of the Alzheimer's type: changes in hippocam pal L- $\left[{ }^{3} \mathrm{H}\right]$ glutamate binding. $J$ Neurochem $1987 ; 48$. 543-51.

17 Geddes JW, Chang-Chui H, Cooper SM, Lott IT, Cotman $C W$. Density and distribution of NMDA receptors in the human hippocampus in Alzheimer's disease. Brain Res 1986;399:156-61.

18 Cowburn R, Hardy J, Roberts P, Briggs R. Regional distribution of pre- and postsynaptic glutamatergic function in Alzheimer's disease. Brain Res 1988;452:403-7.

19 Monaghan DT, Geddes JW, Yao D, Chung C, Cotman CW $\left[{ }^{3} \mathrm{H}\right] \mathrm{TCP}$ binding sites in Alzheimer's disease. Neurosci Lett 1987;73:197-200.

20 Maragos WF, Chu DCM, Young AB, D'Amato CJ, Penney JB. Loss of hippocampal $\left[{ }^{3} \mathrm{H}\right] \mathrm{TCP}$ binding in Alzheimer's disease. Neurosci Lett 1987;74:371-6.

21 Mouradian MM, Contreras PC, Monahan JB, Chase TN $\left[{ }^{3} \mathrm{H}\right] \mathrm{MK}-801$ binding in Alzheimer's disease. Neurosci Lett 1988;93:225-30.

22 Khachaturian ZS. Diagnosis of Alzheimer's disease. Arch Neurol 1985;42:1097-105.

23 Pan HS, Frey KA, Young AB, Penney JB Jr. Changes in [3H]muscimol binding in substantia nigra, entopeduncular nucleus, globus pallidus, and thigra, entopeduncular nucleus, globus pallidus, and thalamus after striatal lesions as demonstrated by quantitative

24 Lorente De No R. Studies on the structure of the cerebral cortex. II. Continuation of the study of the ammonic system. J Psychologie Neurologie 1934;46:113-77.

25 Hyman BT, Van Hoesen GW, Kromer LJ, Damasio AR. Perforant pathway changes and the memory impairmen of Alzheimer's disease. Ann Neurol 1986;20:472-81.

26 Mehraein P, Yamada M, Tarnowska-Dziduszko E. Quantitative study of dendrites and dendritic spines in Alzheimer's disease and senile dementia. Adv Neurol 1975;12:453-8.

27 de Ruiter JP, Uylings HBM. Morphometric and dendritic analysis of fascia dentata granule cells in human aging and analysis of fascia dentata granule cells in hum

28 Catala I, Ferrer I, Galofre E, Fabregues I. Decreased numbers of dendritic spines on cortical pyramidal neurons in dementia. A quantitative Golgi study on biopsy in dementia. A quantitative Golgi study
samples. Human Neurobiol 1988;6:255-9.

29 Coleman PD, Flood DG. Neuron numbers and dendritic extent in normal aging and Alzheimer's disease. Neurobiol Aging 1987;8:521-45.

30 Geddes JW, Monaghan DT, Cotman CW, Lott IT, Kim RC, Chui HC. Plasticity of hippocampal circuitry in Alzheimer's disease. Science 1985;230:1179-81.

31 Maragos WF, Penney JB, Young AB. Anatomic correlation of NMDA and $3 \mathrm{H}-\mathrm{TCP}$-labeled receptors in rat brain. Neurosci 1988;8:493-501.

32 Maragos WF, Greenamyre JT, Penney JB, Young AB. Glutamate dysfunction in Alzheimer's disease: an hypothesis. Trends Neurosci 1987;10:65-8.

33 Novelli A, Reilly JA, Lysko PG, Henneberry RC. Glutamate becomes neurotoxic via the $\mathrm{N}$-methyl-D-aspartate receptor when intracellular energy levels are reduced. Brain Res 1988;451:205-12. 